Drago Župarić-Iljić (ur.)

\section{Prvih deset godina razvoja sustava azila u Hrvatskoj: (s osvrtom na sustave azila u regiji)}

Zagreb: Institut za migracije i narodnosti Centar za mirovne studije - Kuća ljudskih prava, 2013, 279 str.

DOI: $10.11567 /$ met.30.2.8

$\mathrm{U}$ posljednjih trideset godina interes za fenomen izbjeglištva i s njim povezan fenomen migracije $u$ razvijenim je zapadnim industrijaliziranim državama dodatno produbljen. U velikom broji tih država fenomen dolaska sve većeg broja izbjeglica i azilanata postao je prvorazredno političko pitanje za mnoge državne i nedržavne aktere i za javnost općenito. Stavovi prema migrantima $\mathrm{i}$ azilantima sve više profiliraju političku orijentaciju pojedinih političkih stranaka, točnije njihovo lijevo ili desno političko usmjerenje. To se danas posebice odnosi na države Europske unije. U Europi je tijekom 1990-ih zabilježeno naglo osnaživanje migracije povezane s traženjem azila te nezakonitih migracija, odnosno onih koje državne politike tretiraju nezakonitima. Broj tražitelja i nedokumentiranih stranaca (onih koji nezakonito borave u državama) naglo se povećao. Nezakonita migracija postala je jedno od najvažnijih političkih pitanja u Europi tijekom devedesetih godina prošlog stoljeća. Odgovor na pojačani priljev tražitelja azila i migranata bilo je uvođenje sve restriktivnijih politika (policies) koje uključuju sve oštriji nadzor granice, odbijanje da se tražiteljima azila prizna izbjeglički status te sve restriktivniji pravni okvir.

Nakon pristupanja Hrvatske Europskoj uniji sve veći broj tražitelja azila i izbjeglica dolazi na hrvatske granice. Istraživanja su pokazala da je sustav azila u Hrvatskoj još uvijek nespreman za prihvat većeg broja ljudi. To se posebice odnosi na nedostatak i neosmišljenost integracijskih politika i praksi koje su nužne za uključenje većeg broja izbjeglica u hrvatsko društvo. Zabilježene su i negativne reakcije javnosti i građana na dolaske većeg broja stranaca i izbjeglica, što se može činiti iznenađujućim jer je tijekom rata devedesetih u Hrvatsku došao veliki broj izbjeglica. Zbornik Prvih deset godina razvoja sustava azila u Hrvatskoj: (s osvrtom na sustave azila u regiji) donosi prvi cjelovit znanstveni i stručni prikaz te analizu razvoja hrvatskoga azilnog sustava koji je nastao kao odgovor na dolazak »novih izbjeglica«, tražitelja azila. Nastao je u sklopu znanstvene suradnje Instituta za migracije i narodnosti te Centra za mirovne studije u Zagrebu.

Sustav azila razvio se u okvirima međunarodnoga izbjegličkog i humanitarnog prava u svrhu priznanja i zaštite izbjeglica koje u Hrvatskoj traže utočište. Razvoj sustava bio je pod ključnim utjecajem uključivanja $\mathrm{Hr}$ vatske u eurointegracijske procese. Ulaskom u Europsku uniju hrvatski je sustav na normativno-pravnoj razini gotovo potpuno usklađen s europskom pravnom stečevinom u područjima azila, migracija te zaštite ljudskih i izbjegličkih prava. Za razliku od normativne razine na institucionalnoj su zabilježene mnoge manjkavosti. Zbornik okuplja radove teoretičara i praktičara koji su na različite načine bili uključeni u sustav azila te poznaju glavne probleme i manjkavosti sustava. Tako većina radova problemu azilnog sustava pristupa kritički s intencijom daljnjeg poboljšanja i prilagodbe 
sustava dolasku sve većeg broja izbjeglica. Osim toga zbornik je dobrodošao prilog upoznavanju znanstvene, ali i šire javnosti s osnovnim pojmovima, procesima i problemima azila $u$ Hrvatskoj i regiji. Podijeljen je na četiri cjeline i obuhvaća četrnaest radova koje je napisalo devetnaest autora i autorica.

U prvoj cjelini Razvoj zakonodavnog okvira sustava azila u Hrvatskoj nalaze se radovi koji opisuju i analiziraju pravno-normativni okvir razvoja instituta i sustava azila u Hrvatskoj. Goranka Lalić Novak prikazuje tri faze razvoja sustava, nazivajući ih formativnom, transformativnom i fazom stabilizacije. Autorica propituje pravni okvir sustava azila s obzirom na pravo na pristup sustavu azila te pravo na utvrđivanje i priznavanje izbjegličkog statusa. Iris Goldner Lang analizira načelo solidarnosti kao jedan od temeljnih političkih principa Europske unije promatrajući moguće mjere koje države članice mogu poduzeti kako bi poduprle praktično ostvarenje tog principa. Nika Bačić analizira uvođenje Dublinske uredbe u pravni sustav azila Europske unije i njezinu primjenu. Autorica je mišljenja da je potrebna korjenita promjena proceduralnog sustava azila propitujući spremnost Hrvatske da pruži zadovoljavajuću razinu zaštite izbjeglicama. Vanja Bakalović kritički vrednuje propise EU-a o uspostavi standarda u području utvrđivanja činjenica u zahtjevima za azil, prije svega u tzv. Kvalifikacijskoj direktivi, koja sadržava propise o procjeni činjenica i okolnosti kojima tražitelj azila nastoji potkrijepiti svoj zahtjev. Budimir, Paska i Tučkorić analiziraju razvoj hrvatskog zakonodavnog okvira pružanja besplatne pravne pomoći tražiteljima azila. Posebno se osvrću na prakse pružanja pomoći Hrvatskog pravnog centra od donošenja prvog Zakona o azilu do danas.

Druga cjelina Institucionalni $i$ sociokulturni aspekti sustava azila u Hrvatskoj bavi se temama koje obuhvaćaju teorijske i praktične uvide $\mathrm{u}$ razvoj i implementaciju azilnih i integracijskih politika za osobe pod zaštitom u Hrvatskoj. Vedrana Baričević daje pregled zajedničkih europskih politika azila i migracija. Autorica analizira specifičnosti razvoja hrvatskoga azilnog sustava posebno se osvrćući na pitanje implementacije europskih politika u nacionalne sustave. Tea Vidović kroz iskustva korisnika propituje hrvatski zakonodavni i institucionalni okvir sustava azila. Pupačić, Kadoić i Orešković opisuju aktivnosti pružanja usluga psihosocijalne, obrazovne $\mathrm{i}$ humanitarne asistencije $\mathrm{u}$ integraciji izbjeglica i tražitelja azila kroz propitivanje uloge Hrvatskoga Crvenoga križa te raspravljaju o detektiranim potrebama osoba pod zaštitom kako bi se izgradio uspješan model za integraciju izbjeglica. Bužinkić i Kranjec analiziraju na koji način je proces pristupanja Hrvatske EU-u utjecao na razvoj sustava azila posebno se fokusirajući na posljedice ulaska u nove okvire politika i praksi Zajedničkoga europskog azilnog sustava uspoređujući iskustva Bugarske, Rumunjske, Slovenije i Italije $\mathrm{u}$ tom području.

U trećoj cjelini Stavovi javnosti $i$ domaćih aktera prema problematici azila $u$ Hrvatskoj dva rada tematiziraju stavove lokalne javnosti, državnih tijela, medija i ostalih bitnih aktera uključenih u sustav azila. Rad Nikole Petrovića, utemeljen na studiji otpora izgradnji centra za tražitelje azila u naselju Stubička Slatina 2004., bavi se analizom različitih diskursa kojima su se 
izražavali stavovi aktera o tražiteljima azila. Drago Župarić-Iljić opisuje stavove javnosti te analizira medijske prikaze tražitelja azila u kojima ih se percipira kao moguću i stvarnu prijetnju. Radovi okupljeni pod naslovom Iskustva razvoja sustava $i$ politika azila u susjednim zemljama regije usmjereni su na primjere politika azila iz Srbije, Bosne i Hercegovine te Makedonije te čine završnu cjelinu ovoga zbornika.

Zaključno se može reći da je ovaj zbornik izuzetno vrijedan prilog, prvi takve vrste u Hrvatskoj, multidisciplinarnom i sustavnom proučavanju fenomena izbjeglištva i azila nakon završetka rata devedesetih. Okupljeni autori i radovi pristupaju fenomenu izbjeglištva na različite načine, uzimajući u obzir globalni i nadnacionalni kontekst nastajanja fenomena. U tim nastojanjima izrazito je vidljiv kritički aspekt proučavanja s ciljem poboljšavanja sustava i podizanja svijesti različitih zainteresiranih aktera, ali i šire javnosti. On će poslužiti i kao izvor informacija i poticaj za rad na problematici azila znanstvenoj i stručnoj javnosti te kao korektiv i pomoć akterima i praktičarima u sustavu azila. Zbornik je vrijedan prilog u nastojanjima da se tražiteljima azila i izbjeglicama otvori put u njihovim nastojanjima da uspostave život vrijedan življenja u Hrvatskoj i zemljama regije.

Duško Petrović

Filozofski fakultet Sveučilišta u Zagrebu, Zagreb 